\title{
Levels of polychlorinated dibenzo- $p$-dioxins and dibenzofurans in China and chemometric analysis of potential emission sources
}

\author{
Jianxin Zhu ${ }^{\mathrm{a}, *}$, Yasuhiro Hirai ${ }^{\mathrm{b}}$, Gang $\mathrm{Yu}^{\mathrm{c}}$, Shin-ichi Sakai ${ }^{\mathrm{b}, \mathrm{d}}$ \\ ${ }^{a}$ Research Center for Eco-Environmental Sciences, Chinese Academy of Sciences, No. 18 Shuangqing Road, Haidian District, Beijing 100085, China \\ ${ }^{\mathrm{b}}$ Kyoto University, Environment Preservation Center, Sakyo-ku, Kyoto 606-8501, Japan \\ ${ }^{\mathrm{c}}$ Department of Environmental Science and Technology, Tsinghua University, Beijing 100084, China \\ ${ }^{\mathrm{d}}$ Research Center for Material Cycles and Waste Management, National Institute for Environmental Studies, \\ 16-2 Onogawa, Tsukuba-Shi, Ibaraki 305-8506, Japan
}

Received 26 April 2007; received in revised form 20 June 2007; accepted 20 June 2007

Available online 6 August 2007

\begin{abstract}
Aimed to give a preliminary image of dioxin pollution in China, chemometric analysis was performed to determine background dioxin levels during the period 1994-2002 and potential emission sources. Using principal components analysis (PCA), the congener profiles of 71 sediment samples from rivers, lakes, and sea bays around China were compared with the congener profiles of various known or suspected industrial, residential, and municipal dioxin sources to determine whether the dioxin residues typically found in a broad range of potential environmental sources could explain the presence of these chemicals in China. It was found that the background dioxin levels of China were similar to those of lightly polluted samples from other countries during the period 1994-2002. Primary ferrous ore sintering and secondary lead and aluminum smelters were the major sources of dioxin emission in China. Chloranil and wastewater from chemical plants, sodium pentachlorophenate, and pulp bleaching were also important sources of dioxin emission. Open burning of e-waste as well as diesel-fueled and leaded gas-fueled vehicles were additional possible sources of dioxin. In contrast to other countries, in China, flue gases from incineration of municipal waste, hazardous waste, and medical waste might be minor sources of dioxin emission.
\end{abstract}

(c) 2007 Elsevier Ltd. All rights reserved.

Keywords: Principal components analysis; Congener profile; Potential emission sources; China; Sodium pentachlorophenate; Pulp bleaching; e-Waste

\section{Introduction}

Persistent organic pollutants (POPs) are toxic chemicals that persist in the environment, are liable to bioaccumulation through the food web, and pose a risk of adversely affecting human health and the environment. Historically, nine of a dozen POPs have been intentionally or unintentionally produced in China. On June 25, 2004, the Chinese government ratified the Stockholm Convention on POPs. As part of this agreement, in November 2006, China will be required to submit its National Implementation Plan to the Conference of Party, together with a national inven-

\footnotetext{
* Corresponding author. Tel.: +86 106284 9488; fax: +86 1062849515 . E-mail address: zhujx@rcees.ac.cn (J. Zhu).
}

tory of the polychlorinated dibenzo-p-dioxins and polychlorinated dibenzofurans (PCDD/Fs).

In China, relatively few studies of PCDD/Fs have been carried out in comparison to the number of studies on organochlorine pesticides and polychlorinated biphenyls (Fu et al., 2003; Liu et al., 2004; Chen et al., 2005; Wong et al., 2005). However, because of China's huge size and the high cost of dioxin-monitoring, launching many large-scale dioxin-monitoring projects in China is not feasible. Moreover, PCDD/Fs are unintentionally produced in many industries throughout the country, making the issue of dioxin pollution difficult and complex to address. Therefore, identification of the major sources of dioxin emission is important for taking better countermeasures to efficiently control and reduce dioxin pollution. 
Recently, Alcock et al. (2001) and Everaert and Baeyens (2002) showed that PCDD/F emission sources have unique congener profiles and that similar industrial processes have similar emission fingerprints. Chemometric analysis is an effective and efficient tool for identifying a dioxin emission source (Okeefe et al., 1994; Buekens et al., 2000; Alcock et al., 2002; Lee et al., 2004; Schmid et al., 2005). Here, chemometric analysis was used to study dioxin pollution in China. PCDD/F levels in air, water, soil, and sediment samples collected around China over a period of about 10 years were examined and the potential emission sources were determined by principal components analysis (PCA). This study should be helpful in creating a PCDD/F inventory for China and in developing a strategy for reduction of PCDD/Fs in China.

\section{Materials and method}

\subsection{PCDD/F samples description}

$\mathrm{PCDD} / \mathrm{F}$ levels in air, water, soil, and sediment samples and their congener profiles were collected around China over a period of about 10 years. More than half of the recent research on dioxins in China has focused on sediment samples. Fig. 1 shows the locations where sediment samples were collected from 1994 to 2002, and Table 1 lists their PCDD/F levels. Most of these samples were collected in the southeastern part of the country, covering a large area and several important water systems: the Yangtze
River - the largest river in China - and its catchments; the Liao He River in the Northeast; the Pearl and Liangjiang Rivers in the South; the Nanpaiwu River in Tianjin; Poyang Lake; Dongting Lake; Ya-Er Lake; Bohai Bay; and Hong Kong Bay.

The sediment and soil samples were extracted by Soxhlet method and cleaned by several liquid chromatographic purification steps, including: alumina, multilayer silica and florisil columns (Wu et al., 1997). Multilayer silica column purification was commonly adopted, but the composition and structure of the column varied between different researchers (Luksemburg et al., 1996; Zheng et al., 1997; Wu et al., 2001a; Chen et al., 2003b; $\mathrm{Hu}$ et al., 2005). Water samples were enriched by XAD (Suplco Company), then freeze-dried and extracted by Soxhletapparatus (Wu et al., 2001b). Air sampling of PCDD/Fs was conducted by semi-volatile samplers (Model GPS-1, Graseby Andersen, USA) and a precleaned PUF plug ( $6 \mathrm{~cm}$ diameter, $7.5 \mathrm{~cm}$ length). Sample clean-up included liquid-liquid partition with $20 \% \mathrm{w} / \mathrm{v}$ potassium hydroxide solution and concentrated sulphuric acid, and column chromatography using mixed silica and alumina (Louie and Sin, 2003). The PCDD/F samples were analyzed according to US EPA Method 1613A or Japanese Industry Standard Method K0311. The identification of PCDD/Fs was accomplished with high resolution gas chromatography-mass spectrometry. Quantization of $\mathrm{PCDD} / \mathrm{Fs}$ was performed in selected-ion monitoring mode (Luksemburg et al., 1996; Chen et al., 2003a; Hu et al., 2005).

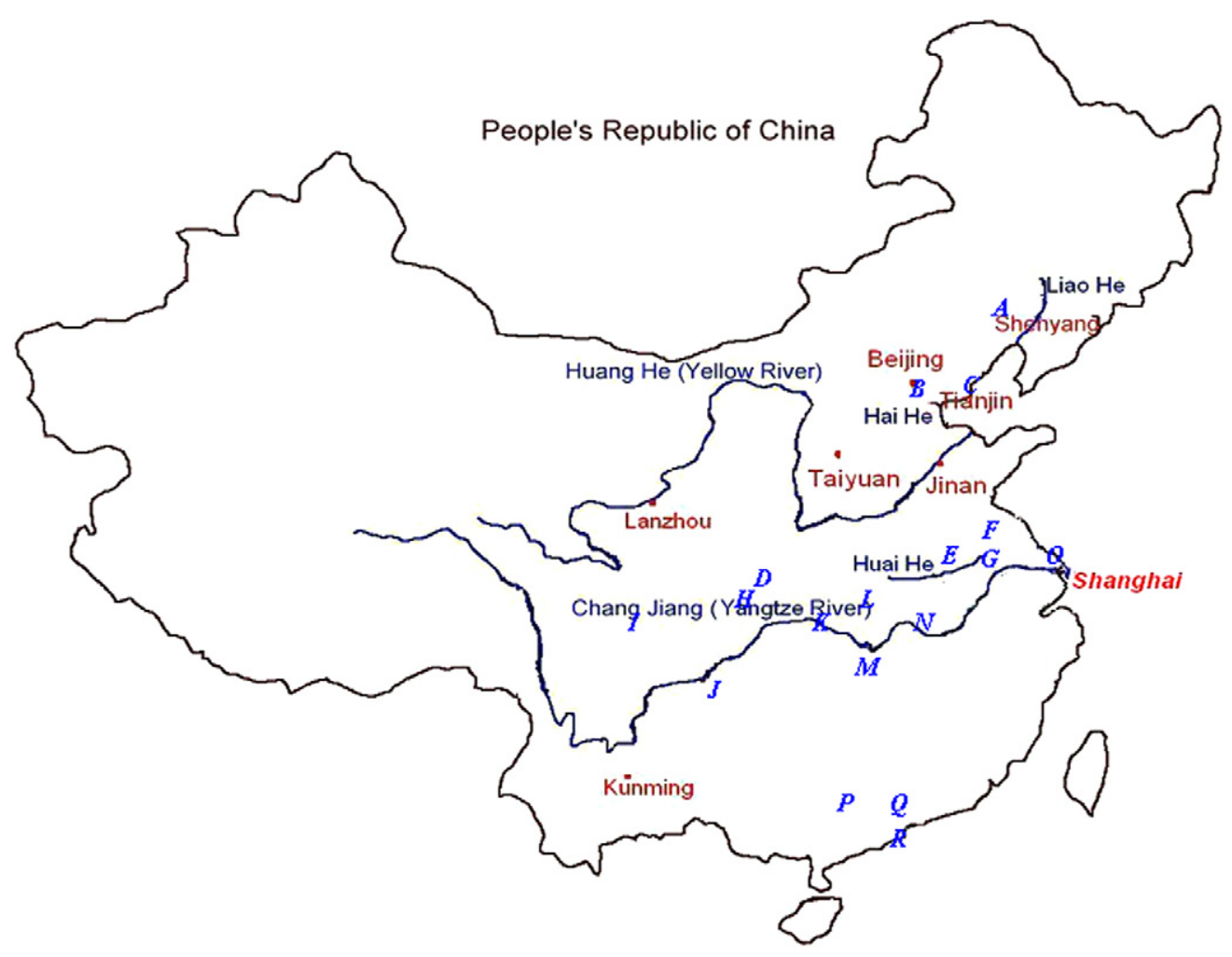

Fig. 1. Surficial sediment sampling locations. 
Table 1

Sampling locations and PCDD/F levels of the sediment samples

\begin{tabular}{|c|c|c|c|c|c|c|}
\hline Sample & Water system & Position in Fig. 1 & Number of samples & $\mathrm{PCDD} / \mathrm{F}$ concn range $\left(\mathrm{pg} \mathrm{g}^{-1}\right)$ & Year & Reference \\
\hline $1-4$ & Ya-Er Lake & $\mathrm{D}$ & 4 & $61-33837$ & 1994 & Wu et al. (1997) \\
\hline $5-9$ & Ya-Er Lake & $\mathrm{D}$ & 5 & $2100-6620$ & 1997 & Wu et al. (2001a) \\
\hline $10-17$ & Dongting Lake & $\mathrm{J}$ & 8 & $52617-233304$ & 1995 & Zheng et al. (1997) \\
\hline $18-24$ & Dongting Lake & $\mathrm{J}$ & 7 & 641-1881 & 1999 & Zheng et al. (2003) \\
\hline $25-31$ & Liangjiang River & Q & 7 & $56-743180$ & 2002 & Luksemburg et al. (2002) \\
\hline $32-38$ & Dagu & B & 7 & $425-1456170$ & 2001 & Luksemburg et al. (2001) \\
\hline 39 & Bengbu Harbor & $\mathrm{F}$ & 1 & 129 & 1995 & Luksemburg et al. (1996) \\
\hline 40 & Hongze Lake & G & 1 & 62.09 & 1995 & Luksemburg et al. (1996) \\
\hline 41 & Grand Canal & $\mathrm{F}$ & 1 & 58.5 & 1995 & Luksemburg et al. (1996) \\
\hline 42 & Fu River & I & 1 & 103.9 & 1995 & Luksemburg et al. (1996) \\
\hline 43 & Nanfei River & $\mathrm{L}$ & 1 & 3944.5 & 1995 & Luksemburg et al. (1996) \\
\hline 44 & Dongting Lake & $\mathbf{J}$ & 1 & 267.86 & 1995 & Luksemburg et al. (1996) \\
\hline 45 & Han River & $\mathrm{H}$ & 1 & 13.52 & 1995 & Luksemburg et al. (1996) \\
\hline 46 & Poyang Lake & M & 1 & 900.49 & 1995 & Luksemburg et al. (1996) \\
\hline $47-50$ & Yangtze River & $\mathrm{N}$ & 4 & $162.4-462.0$ & 1995 & Luksemburg et al. (1996) \\
\hline $51-52$ & Huangpu River & $\mathrm{O}$ & 2 & $65.29-178.29$ & 1995 & Luksemburg et al. (1996) \\
\hline 53 & Huaihe River & $\mathrm{E}$ & 1 & 515.4 & 1995 & Luksemburg et al. (1996) \\
\hline $54-60$ & Hong Kong Bay & $\mathrm{R}$ & 7 & $314-10997$ & 2001 & Muller et al. (2002) \\
\hline $61-68$ & Pearl River & $\mathrm{P}$ & 8 & $498-2590$ & 1997 & Zheng et al. (2001) \\
\hline 69-70 & Nanpaiwu River & B & 2 & $121302-3289600$ & 2002 & Hu et al. (2005) \\
\hline 71 & Bohai Bay & $\mathrm{C}$ & 1 & 447.8 & 2002 & Hu et al. (2005) \\
\hline$-{ }^{\mathrm{a}}$ & Yangtze River & $\mathrm{N}$ & 2 & $751-1024$ & 1998 & Martens et al. (2000) \\
\hline$-^{\mathrm{a}}$ & Yangtze River & $\mathrm{K}$ & 1 & 23197 & 1999 & Martens et al. (2000) \\
\hline$-^{\mathrm{a}}$ & Liao He River & A & 1 & 18.3 & 1999 & Martens et al. (2000) \\
\hline
\end{tabular}

${ }^{a}$ Only the TEQ level was reported; no information about the congener profile was provided.

\subsection{Congener profiles of the suspected emission sources}

Fig. 2 shows congener profiles of the suspected sources of dioxin emission. The congener profiles for sodium pentachlorophenate, chloranil, wastewater from chemical plants, pulp bleaching, diesel-fueled vehicles, and open burning of e-waste were derived from studies pertaining to China (Schecter et al., 1994; Bao et al., 1995; Jiang et al., 1995; Luksemburg et al., 1996; Zhang et al., 2000a,b, 2002; Luksemburg et al., 2002; Lee et al., 2004). The other profiles (profiles for emissions from municipal solid waste incineration (MSWI), hazardous waste incineration (HWI), medical waste incineration (MeWI), crematoria, leaded gas-fueled vehicles, unleaded gas-fueled vehicles, utilities and industrial boilers, cement kilns not burning hazardous waste, primary ferrous ore sintering, secondary aluminum smelters, secondary copper refining, and secondary lead smelters) were derived from the dioxin database compiled by the US Environmental Protection Agency (US-EPA) ((US-EPA), 2001). Paralleling the results for the sediment samples, OCDD was the dominant compound in most of the emission sources.

\subsection{Principal components analysis}

SPSS 13 (Apache Software Foundation) was adopted for the principal components analysis of the 71 surficial sediment samples listed in Table 1. The congener profiles of these samples were compared with the congener profiles of suspected industrial, residential, and municipal sources of dioxin to determine whether the PCDD/F residues typically found in a broad range of potential environmental sources could explain the presence of these chemicals in China.

To reduce the effect of concentration differences among the sediment samples, the data were normalized before calculation. The foregoing analysis showed that OCDD is preponderant in both the sediment samples and the dioxin emission sources, so OCDD could overwhelm the influence of less dominant congeners during normalization by relative concentration. Therefore, the congener profiles for the 17 possible 2,3,7,8-substituted congeners were generated as follows: For the sixteen 2,3,7,8-substituted congeners exclusive of OCDD, normalization was implemented by dividing the concentration of each congener by the sum of the concentrations of all 16 congeners. OCDD was normalized by dividing its concentration by the sum of the concentrations of all 17 possible 2,3,7,8substituted congeners. Concentrations that were below the detection limit were treated as the half of the detection limit.

\section{Results and discussion}

\subsection{PCDD/F levels in environmental samples}

The PCDD/F concentrations of the sediment samples vary from 14 to $3,289,600 \mathrm{pg} \mathrm{g}^{-1}$ (Table 1). The OCDD mass fraction was about $80 \%$. The minor pollutant sample 

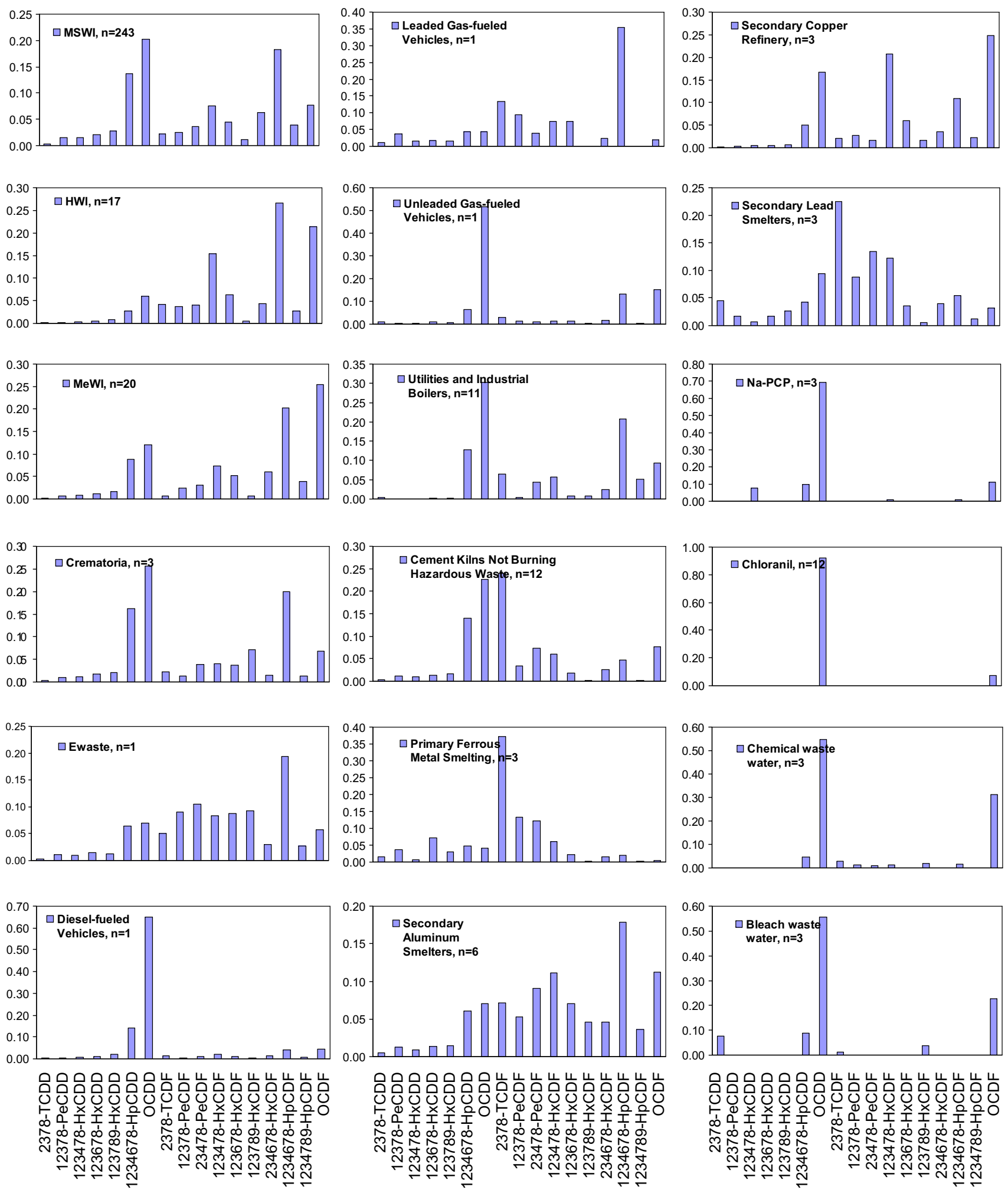

Fig. 2. PCDD/F congener profiles of some emission sources.

was collected at Han River and Liao He River, while the major pollutant samples were collected at Nanpaiwu River and Dagu Bay in Tianjin, where many large chemical plants were located. The PCDD/F concentrations of most

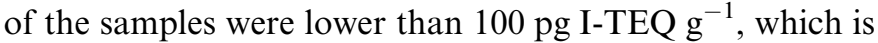

quite close to values for lightly polluted rivers and bays in other countries, e.g., the Tama River, Tokyo Bay, and Osaka Bay in Japan (Onodera et al., 1999; Hosomi et al., 2003; Takigami et al., 2005); the Lower Great Lakes, North America (Marvin et al., 2002); and the Po River 
and Venice Lagoon, Italy (Frignani et al., 2001; Fattore et al., 2002).

$\mathrm{Wu}$ et al. (2001b) showed that PCDD/Fs, other than hexachlorocyclohexane $(\mathrm{HCH})$, were prominent pollutants in some areas of the Yangtze River after production of $\mathrm{HCH}$ was banned in the late 1990s. Ya-Er Lake, located along the middle-lower reaches of the Yangtze River, had $\mathrm{PCDD} / \mathrm{F}$ levels in the range $0.11-0.43 \mathrm{pg}$ I-TEQ $1^{-1}$. Moreover, all water samples analyzed by $\mathrm{Wu}$ had the same congener profile, and OCDD was the dominant congener. The concentrations of most of the 2,3,7,8-substituted congeners decreased with increasing distance from the wastewater discharge of a pesticide plant.

In 1994, soil samples from rice and cotton fields in Hubei Province, southern China, were collected for analysis of pollutants. The fields were suspected of being polluted by pesticides and contaminated irrigation water. The mean $\mathrm{PCDD} / \mathrm{F}$ concentrations in the samples were about $26.21 \mathrm{pg} \mathrm{g}^{-1}\left(0.11 \mathrm{pg} \mathrm{I}^{-T E Q ~ g}{ }^{-1}\right)$ for samples from the cotton field and $95.55 \mathrm{pg} \mathrm{g}^{-1}\left(1.30 \mathrm{pg}\right.$ WHO-TEQ $\left.\mathrm{g}^{-1}\right)$ for samples from the rice field ( $\mathrm{Wu}$ et al., 1998; Wu et al., 2002). The congener profiles of the samples showed high proportions of OCDD, OCDF, and 1234678HpCDD. Later, in September 2002, Chen studied 42 surface soil samples collected around Beijing in northern China and found that the background dioxin level of the samples was about $0.88 \mathrm{pg} \mathrm{WHO-TEQ} \mathrm{g}^{-1}$ (Chen et al., 2003b). This value is comparable to that for lightly polluted urban and industrial soil of other countries [e.g., 0.7$1.5 \mathrm{pg} \mathrm{I-TEQ} \mathrm{g}^{-1}$ in Italy (Caserini et al., 2004), 1.1$11 \mathrm{pg} \mathrm{I}^{-T E Q ~ \mathrm{~g}^{-1}}$ in Switzerland (Schmid et al., 2005) and 0.13-24.20 $\mathrm{pg} \mathrm{I}^{-T E Q ~ g}{ }^{-1}$ in Spain (Schuhmacher et al., 2002)], lower than the background level for soil in Tokyo

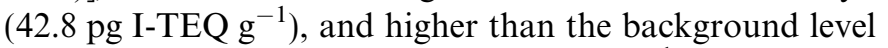
for unpolluted areas [e.g., $0.16 \mathrm{pg}$ I-TEQ $\mathrm{g}^{-1}$ in Spain and 0.4 4.27 pg I-TEQ $\mathrm{kg}^{-1}$ in Japan (Sakurai et al., 2000)].

Dioxin-monitoring data for ambient air samples were available only for Hong Kong. There is still no regular dioxin-monitoring net in mainland China. The PCDD/F concentration in Hong Kong varies from 40 to $180 \mathrm{fg}^{\mathrm{I}-T E Q ~ \mathrm{~m}^{-3}}$, depending on the season (Louie and Sin, 2003). In this paper, the soil-air partition coefficient $\left(K_{\mathrm{SA}}\right)$ and plant-air partition coefficient $\left(K_{\mathrm{PA}}\right)$ (Chen et al., 2003a) were employed to assess the level of PCDD/Fs in the ambient air of Beijing and Dalian. Assuming gas-phase equilibrium (i.e., assuming atmospheric burdens were mainly due to a mixture of primary sources and did not involve revolatilization from the soil), a PCDD/F concentration of about $35.6 \mathrm{fg} \mathrm{I}^{\mathrm{T}} \mathrm{TEQ} \mathrm{m}^{-3}$ was calculated for Beijing. This value is comparable to the values for the urban air of Spain (10-357 $\mathrm{fg} \mathrm{I}^{-T E Q ~ \mathrm{~m}^{-3}}$ ), Brazil (47-751 pg I-TEQ $\mathrm{m}^{-3}$ ), and Athens (166.6-701.5 fg I-TEQ $\mathrm{m}^{-3}$ ) (Abad et al., 2002; Assuncao et al., 2005; Moon et al., 2005). The ambient air of Dalian, which is a tourism city in northeastern China, had a PCDD/F level of $2.72 \mathrm{fg}^{\mathrm{I}}$-TEQ $\mathrm{m}^{-3}$, a value that is much lower than that for Beijing.

\subsection{PCA of the sediment samples}

Five principal components (PC1-PC5) with latent roots or eigenvalues above 1.0 were extracted by SPSS for the normalized 71 sediment samples. These five components represent about $68.47 \%$ of the total components. Fig. 3a-c show plots of PC1 vs PC2, PC3 vs PC4, and PC4 vs PC5 for the 2,3,7,8-substituted compounds. These plots graphically tell us the mass fraction of each 2,3,7,8-substituted compound in each component: the higher the value for a compound, the greater its mass fraction in the principal component.

In Fig. 3a (a plot of the first two principal components), the $Y$ coordinate is the first principal component (PC1), which explains $21.76 \%$ of the variance, and the $X$ coordinate is $\mathrm{PC} 2$, which explains $13.92 \%$ of the variance. $\mathrm{PC} 1$ mainly represents 23478-PeCDF, 2378-TCDF, 123789-HxCDF, 12378-PeCDF, 123678-HxCDF, and 123478-HxCDF. It reveals that the following sources are responsible for these compounds: primary ferrous ore smelting, secondary lead smelters, open burning of e-waste, and secondary aluminum smelters. The second principal component (PC2) mainly represents OCDF, 123678-HxCDD, 123789HxCDD, and 1234678-HpCDD, whose potential sources are chloranil and wastewater from chemical plants.

Fig. $3 \mathrm{~b}$ shows a plot of the third principal component (PC3) vs the fourth principal component (PC4). PC3 mainly represents 1234789-HpCDF, 1234678-HpCDF, 123478-HxCDF, 123678-HxCDF, OCDD, and 1234678HpCDD. Potential sources of these compounds are sodium pentachlorophenate, chloranil, wastewater from chemical plants, diesel-fueled vehicles, pulp bleaching, hazardous waste incineration, and leaded gas-fueled vehicles. PC4 has abundant OCDF, 2378-TCDD, 12378-PeCDD, and 123789-HxCDF, and PC5 mainly represents OCDF and 123478-HxCDD (Fig. 3c). Table 2 summarizes the results for the principal components analysis and potential sources of the compounds.

In Fig. 4a-c, the factor scores of the 71 sediment samples are plotted with respect to the first five principal components. The scatterplots allow us to view the positions of the samples on the first five principal components and tell us the relationship of the samples to the principal components.

Fig. 4a shows that samples $31,27,28,41,51,23,53,19$, $6,7,65,25,40,52,39,40$, and 20 have high factor scores on PC1. Therefore, primary ferrous ore sintering, secondary lead smelters, open burning of e-waste, and secondary aluminum smelters are potential sources of dioxins in these samples (Table 2). The fact that these samples were collected from geographically diverse locations covering a very large area, including Ya-Er Lake $(6,7)$, Dongting Lake $(19,20,23)$, Liangjiang River $(25,27,28,31)$, Bengbu Harbor (39), Hongze Lake (40), Grand Canal (41), Huangpu River $(51,52)$, Huaihe River (53), and Hong Kong Bay (65), suggests that many rivers and lakes in China might be polluted by dioxins emitted from both the ferrous and non-ferrous metal industries. 

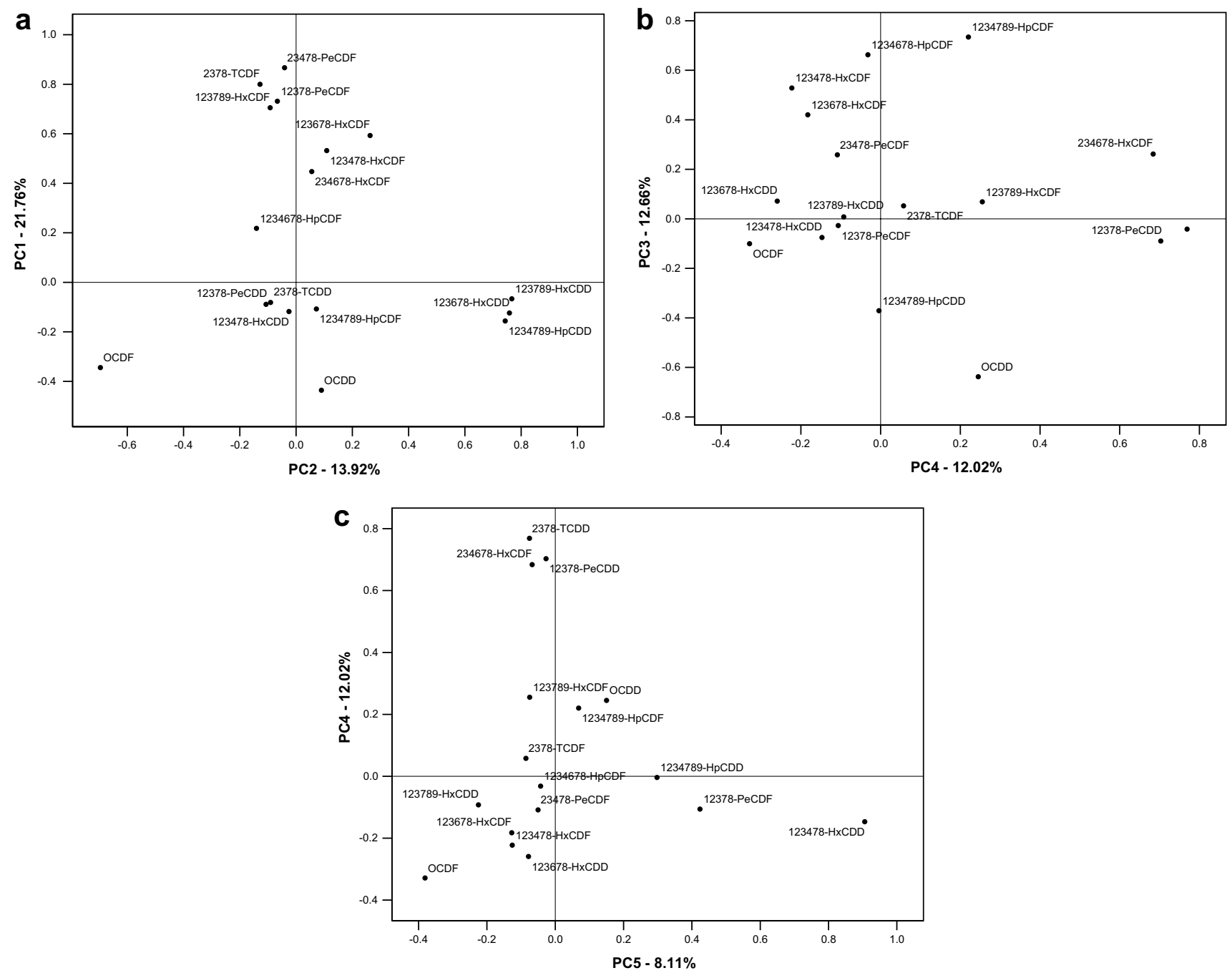

Fig. 3. Plots of the first five principal components: (a) PC1 vs PC2; (b) PC3 vs PC4; (c) PC4 vs PC5.

Table 2

First five principal components and potential sources of the main compounds

\begin{tabular}{|c|c|c|c|c|}
\hline $\begin{array}{l}\text { Principal } \\
\text { component }\end{array}$ & $\begin{array}{l}\% \text { of } \\
\text { variance }\end{array}$ & $\begin{array}{l}\text { Cumulative } \\
\%\end{array}$ & Main compounds & Potential sources \\
\hline 1 & 21.76 & 21.76 & $\begin{array}{l}\text { 23478-PeCDF, 2378-TCDF, 123789- } \\
\text { HxCDF, 12378-PeCDF, 123678-HxCDF, } \\
\text { 123478-HxCDF }\end{array}$ & $\begin{array}{l}\text { Primary ferrous ore smelting, secondary lead smelters, open } \\
\text { burning of e-waste, and secondary aluminum smelters }\end{array}$ \\
\hline 2 & 13.92 & 35.68 & $\begin{array}{l}\text { OCDF, } 123678-\mathrm{HxCDD}, 123789- \\
\mathrm{HxCDD}, 1234678-\mathrm{HpCDD}\end{array}$ & Chloranil, wastewater from chemical plants \\
\hline 3 & 12.66 & 48.34 & $\begin{array}{l}\text { 1234789-HpCDF, 1234678-HpCDF, } \\
\text { 123478-HxCDF, 123678-HxCDF, OCDD, } \\
\text { 1234678-HpCDD }\end{array}$ & $\begin{array}{l}\text { Sodium pentachlorophenate, chloranil, wastewater from } \\
\text { chemical plants, diesel-fueled vehicles, pulp bleaching, } \\
\text { hazardous waste incineration, leaded gas-fueled vehicles }\end{array}$ \\
\hline 4 & 12.02 & 60.36 & $\begin{array}{l}\text { OCDF, 2378-TCDD, 12378-PeCDD, } \\
\text { 123789-HxCDF }\end{array}$ & Unknown \\
\hline 5 & 8.11 & 68.47 & OCDF, 123478-HxCDD & Unknown \\
\hline
\end{tabular}

Because China has the largest ferrous and non-ferrous metal industries in the world, the foregoing result is not surprising. The production of steel in China was about $1.4 \times 10^{8} \mathrm{t}$ in 1996. Using the emission factor $(5 \mu \mathrm{g} \mathrm{I}$ TEQ $\mathrm{t}^{-1}$ ) recommended by the UNEP toolkit for a low- waste, well-controlled plant, one can calculate that, in 1996, about $700 \mathrm{~g} \mathrm{I-TEQ} \mathrm{of} \mathrm{PCDD/Fs} \mathrm{was} \mathrm{emitted} \mathrm{from}$ primary ferrous iron ore sintering plants. In 1996, secondary lead and secondary aluminum smelters produced about $1.8 \times 10^{5} \mathrm{t}$ of lead and $1.9 \times 10^{5} \mathrm{t}$ of aluminum. The emis- 

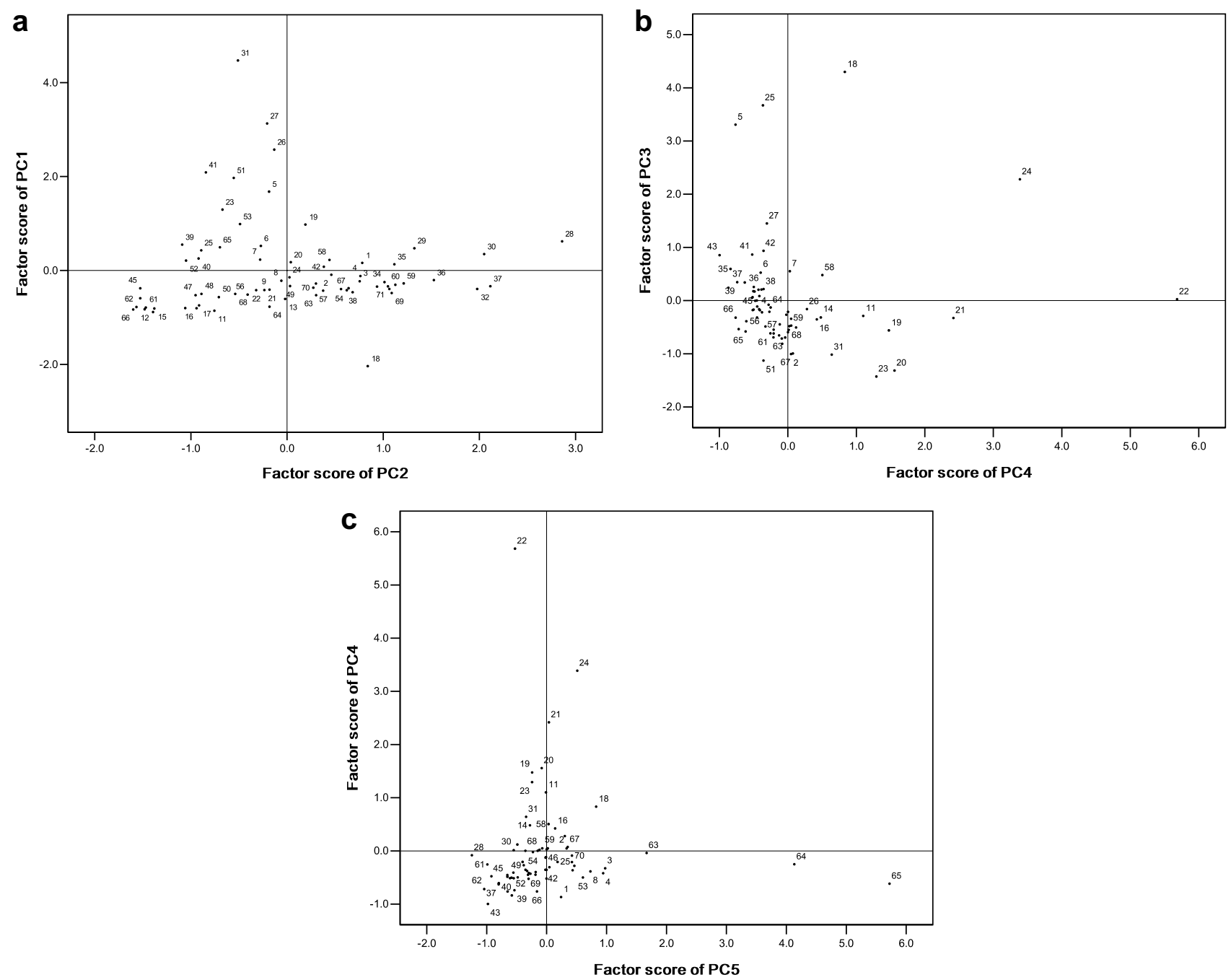

Fig. 4. Factor scores of the 71 sediment samples plotted with respect to the first five principal component: (a) PC1 vs PC2; (b) PC3 vs PC4; (c) PC4 vs PC5.

sion factors (1996 values) recommended by the UNEP toolkit for plants with normal air pollution control were $80 \mu \mathrm{g} \mathrm{I}$-TEQ $\mathrm{t}^{-1}$ of lead and $35 \mu \mathrm{g}$ I-TEQ $\mathrm{t}^{-1}$ of aluminum. Thus, in 1996, the dioxin emissions from secondary lead and secondary aluminum were about 14.4 and $6.7 \mathrm{~g} \mathrm{I}$ TEQ. Therefore, the aforementioned result is simply a consequence of the huge scale of the metal refining industry in China. Regarding emission of dioxins from open burning of e-waste, Luksemburg et al. (2002) analyzed the ash from e-waste burned at Guiyu, Guangdong Province, and found a dioxin level as high as $5.7 \mathrm{ng} \mathrm{I-TEQ} \mathrm{g}^{-1}$ in the ash. Although the extent of open burning of e-waste is difficult to estimate, such burning might be a source of dioxin emission in some cities in southeastern China.

Fig. $4 \mathrm{a}$ also shows that samples $28,30,32,37,36,39,35$, $59,60,69,34,71,33,1,3,4$, and 36 have high factor scores on PC2. Thus, chloranil and wastewater from chemical plants are potential sources of dioxins in these samples (Table 2). The samples were collected from Ya-Er Lake $(1,3,4)$, the Liangiiang River $(28,29,30)$, Dagu (32-37), Hong Kong Bay $(59,60)$, the Nanpaiwu River (69), and
Bohai Bay (71). Dagu, the Nanpaiwu River, and Bohai Bay are just in Tianjin, where there are many large chemical and pesticide plants. In China, the chemical industry produces a large amount of wastewater, about $17.5 \%$ of the total. Some chemical processes involving organochlorines may produce $\mathrm{PCDD} / \mathrm{F}$ byproducts. For example, high concentrations of PCDD/Fs were found in chloranil products (Zhang et al., 2000a; Zhang et al., 2000b) and the wastewater discharged from a pesticide plant (Luksemburg et al., 2001). Thus, because of the large-scale of the chemical industry in China, dioxin emission from related products and wastewater must be seriously considered.

Fig. $4 \mathrm{~b}$ indicates that the dioxins in samples 18, 25, 5, 27, 41-43, and 35-39 might come from sodium pentachlorophenate, chloranil, wastewater from chemical plants, pulp bleaching, hazardous waste incineration, or diesel-fueled and leaded gas-fueled vehicles. In the 1990s sodium pentachlorophenate was widely used to control snail-borne schistosomiasis in southern China, and high concentrations of OCDD, OCDF, and 1234678-HpCDD were found in pentachlorophenol (PCP) and sodium pentachlorophenate 
samples (Schecter et al., 1994; Jiang et al., 1995; Zheng et al., 1999; Hong et al., 2005). Thus, the former use of sodium pentachlorophenate to control snail-borne schistosomiasis might be the source of the PCDD/Fs in samples collected in southern China. The concentration of PCDD/Fs in Na-PCP products was reported to be about 29.9-163.7 ng I-TEQ g ${ }^{-1}$ (Bao et al., 1995; Zheng et al., 1997; Chi and Huang, 2002). Also, pulp bleaching with chlorine will produce PCDD/Fs. Zhang et al. (2000b) reported a PCDD/F concentration of $10.11 \mathrm{pg}^{-1}$ in wastewater from Chinese pulp and paper processing plants.

Unlike developed countries, landfill was still the leading municipal waste disposal method in China, and the incineration ratio was only $4.90 \%$. Most Chinese MSWI facilities are located in eastern and southern provinces, for example, in Shanghai, Zhejiang, and Guangdong. Recent studies have shown that the dominant 2378-substituted congeners detected were OCDD and 1234678-HpCDD, followed by 1234678-HpCDF and OCDF in the flue gases and fly ash of Chinese MSWI facilities. Research has shown that most of the large incinerators in China can meet the national standard for dioxin emissions ( $1 \mathrm{ng}$ TEQ $\mathrm{Nm}^{-3}$ ) ( $\mathrm{Li}$ et al., 2001; Zhang et al., 2004). Comparing with ferrous and non-ferrous industry, the total estimated PCDD/F emissions from Chinese municipal, hazardous, and medical waste incineration combined will be minor. However, municipal solid waste, hazardous and medical waste incineration should not be neglected in the future owing to the rapidly increasing use of incineration anticipated.

Diesel-fueled and gas-fueled vehicles are also important potential sources of dioxin emission. However, some uncertainty exists because only a few samples are available for diesel-fueled vehicles. Moreover, in Japan, where automobiles are more commonly used than in China, dioxins emitted from vehicles amounted to less than $1 \%$ of the total dioxin inventory. Therefore, more data are needed to evaluate whether emissions from vehicles are an important source of dioxins.

\section{Conclusion}

Chemometric analysis of environmental samples collected throughout China from 1994 through 2002 indicated that the background dioxin levels in air, water, soil, and sediment samples from China were similar to those in lightly polluted samples from developed countries. Principal components analysis revealed that primary ferrous ore sintering, secondary lead smelting, and secondary aluminum smelting were the major recent sources of dioxin emission in China. Chemical products, such as chloranil and sodium pentachlorophenate, and wastewater discharge from chemical plants and pulp bleaching operations were also important sources of dioxin emission in China. Open burning of e-waste and diesel-fueled and gas-fueled vehicles were suspected potential sources of dioxin emission. Because China still has a relatively low incineration ratio, incineration of municipal waste, hazardous waste, and medical waste might contribute only slightly to the current total dioxin inventory. In contrast, the recent rapid growth in the ferrous and non-ferrous metal industries might result in a greatly increased emission of $\mathrm{PCDD} / \mathrm{Fs}$ from those industries.

\section{References}

Abad, E., Caixach, J., Rivera, J., Gustems, L., Massague, G., Puig, O., 2002. Surveillance programme on dioxin levels in ambient air sites in Catalonia (Spain). Chemosphere 49, 697-702.

Alcock, R.E., Sweetman, A.J., Anderson, D.R., Fisher, R., Jennings, R.A., Jones, K.C., 2002. Using PCDD/F congener patterns to determine the source of elevated TEQ concentrations in cows milk, a case study. Chemosphere 46, 383-391.

Alcock, R.E., Sweetman, A.J., Jones, K.C., 2001. A congener-specific $\mathrm{PCDD} / \mathrm{F}$ emissions inventory for the UK, do current estimates account for the measured atmospheric burden? Chemosphere 43, 183 194.

Assuncao, J.V., Pesquero, U.R., Bruns, R.E., Carvalho, L., 2005. Dioxins and furans in the atmosphere of Sao Paulo City, Brazil. Chemosphere 58, 1391-1398.

Bao, Z.C., Wang, K., Kang, J.X., Zhao, L.W., 1995. Analysis of polychlorinated dibenzo- $p$-dioxins and polychlorinated dibenzofurans in pentachlorophenol and sodium pentachlorophenate. Environ. Chem. 14, 317-321 (in Chinese).

Buekens, A., Cornelis, E., Huang, H., Dewettinck, T., 2000. Fingerprints of dioxin from thermal industrial processes. Chemosphere 40, 10211024.

Caserini, S., Cernuschi, S., Giugliano, M., Grosso, M., Lonati, G., Mattaini, P., 2004. Air and soil dioxin levels at three sites in Italy in proximity to MSW incineration plants. Chemosphere 54, 1279-1287.

Chen, J.W., Zhao, H.M., Gao, L., Quan, X., Henkelmann, B., Schramm, K.W., 2003a. PCDD/F levels in pine needles sampled from Dalian, China. Organohal. Compd. 51, 494-497.

Chen, Y., Wang, C.X., Wang, Z.J., 2005. Residues and source identification of persistent organic pollutants in farmland soils irrigated by effluents from biological treatment plants. Environ. Int. 31, 778-783.

Chen, Z.S., Li, W., Li, C.Q., Huang, P., Liu, G.Y., Zhou, Z., 2003 b. Background levels of PCDD/Fs in soil of Beijing area, China. Organohal. Compd. 62, 495-498.

Chi, J., Huang, G.L., 2002. A multimedia fugacity river model of pentachlorophenol in South Drainage Canal, China. J. Environ. Sci. Health Part A - Toxic/Hazard. Subst. Environ. Eng. 37, 113-125.

Everaert, K., Baeyens, J., 2002. The formation and emission of dioxins in large scale thermal processes. Chemosphere 46, 439-448.

Fattore, E., Vigano, L., Mariani, G., Guzzi, A., Benfenati, E., Fanelli, R., 2002. Polychlorinated dibenzo- $p$-dioxins and dibenzofurans in River Po sediments. Chemosphere 49, 749-754.

Frignani, M., Bellucci, L.G., Carraro, C., Raccanelli, S., 2001. Polychlorinated biphenyls in sediments of the Venice Lagoon. Chemosphere 43, 567-575.

Fu, J.M., Mai, B.X., Sheng, G.Y., Zhang, G., Wang, X.M., Peng, P.A., Xiao, X.M., Ran, R., Cheng, F.Z., Peng, X.Z., Wang, Z.S., Tang, U.W., 2003. Persistent organic pollutants in environment of the Pearl River Delta, China, an overview. Chemosphere 52, 1411-1422.

Hong, H.C., Zhou, H.Y., Luan, T.G., Lan, C.Y., 2005. Residue of pentachlorophenol in freshwater sediments and human breast milk collected from the Pearl River Delta, China. Environ. Int. 31, 643649.

Hosomi, M., Matsuo, T., Dobashi, S., Katou, S., Abe, H., 2003. Survey of dioxins in Tokyo Bay bottom sediment. Mar. Pollut. Bull. 47, 68-73.

Hu, J.Y., Wan, Y., Shao, B., Jin, X., An, W., Jin, F., Yang, M., Wang, X.J., Sugisaki, M., 2005. Occurrence of trace organic contaminants in Bohai Bay and its adjacent Nanpaiwu River, North China. Mar. Chem. 95, 1-13. 
Jiang, K., Li, L.J., Chen, Y.D., Li, S.B., Gong, Y.F., 1995. Residual dioxins in Chinese schistosomiasis region and its eco-environmental risk. Chin. Sci. Bull. 40, 1740-1747.

Lee, W.S., Chang-Chien, G.P., Wang, L.C., Lee, W.J., Tsai, P.J., Wu, K.Y., Lin, C., 2004. Source identification of PCDD/Fs for various atmospheric environments in a highly industrialized city. Environ. Sci. Technol. 38, 4937-4944.

Li, X.D., Gu, Y.L., Ni, M.J., Cen, K.F., 2001. Study of PCDD/F emissions from an MSW fluidized bed incinerator. J. Eng. Thermophys. 22, 526-528 (in Chinese).

Liu, M., Yang, Y., Xu, S., Hou, L., Liu, Q., Ou, D., Jiang, H. , 2004 Persistent organic pollutants (POPs) in intertidal surface sediments from the Yangtze estuarine and coastal areas, China. J. Coast. Res. 43 (special issue), 162-170.

Louie, P., Sin, D., 2003. A preliminary investigation of persistent organic pollutants in ambient air in Hong Kong. Chemosphere 52, 1397-1403.

Luksemburg, W., Wong, A., Maier, M., Spasl, R., Zhou, H., 2001. A follow-up study of polychlorinated dibenzodioxin and dibenzofuran near a pesticide plant in Dagu, China. Organohal. Compd. 51, 223 225 .

Luksemburg, W.J., Mitzel, R.S., Peterson, R.G., Hedin, J.M., Maier, M., Schuld, M., Zhou, H., Wong, A.S., 2002. Polychlorinated dibenzodioxins and dibenzofurans (PCDDs/PCDFs) levels in environmental and human hair samples around an electronic waste processing site in Guiyu, Guangdong Province, China. Organohal. Compd. 55, 347-349.

Luksemburg, W.J., Mitzel, R.S., Zhou, H., Hedin, J.M., Silverbush, B.B., Wong, A.S., 1996. Polychlorinated dioxins and dibenzofurans in environmental samples from China. Organohal. Compd. 28, 262-266.

Martens, D., Zhang, A., Jiang, X., Chen, J., Gawlik, B.M., Henkelmann, B., Schramm, K.W., Kettrup, A., 2000. Polychlorinated dibenzo-pdioxins and dibenzofurans, pentachlorophenol, pentachloroanisole and hexachlorobenzene in sediments of the Yangtse River and the Liao-He River in China. Organohal. Compd. 46, 431-434.

Marvin, C., Alaee, M., Painter, S., Charlton, M., Kauss, P., Kolic, T., MacPherson, K., Takeuchi, D., Reiner, E., 2002. Persistent organic pollutants in Detroit River suspended sediments, polychlorinated dibenzo-p-dioxins and dibenzofurans, dioxin-like polychlorinated biphenyls and polychlorinated naphthalenes. Chemosphere 49, 111120.

Moon, H.B., Lee, S.J., Choi, H.G., Ok, G., 2005. Atmospheric deposition of polychlorinated dibenzo-p-dioxins (PCDDs) and dibenzofurans (PCDFs) in urban and suburban areas of Korea. Chemosphere 58, $1525-1534$.

Muller, J.F., Gaus, C., Prange, J.A., Papke, O., Poon, K.F., Lam, M.H., Lam, P.K., 2002. Polychlorinated dibenzo-p-dioxins and polychlorinated dibenzofurans in sediments from Hong Kong. Mar. Pollut. Bull. 45, 372-378.

Okeefe, P., Smith, R., Conner, S., Aldous, K., Valente, H., Donnelly, R., 1994. Principal components analysis of polychlorinated dibenzo- $p$ dioxins and polychlorinated dibenzofurans in sediments from Lake Champlain and Lake George, New York, USA. Arch. Environ. Contam. Toxicol. 27, 357-366.

Onodera, S., Sugimoto, M., Takagi, T., Tanaka, K., 1999. Polychlorinated dibenzo-p-dioxins and dibenzofurans, their concentrations and profiles in sediments in the Tama River, Japan. Jpn. J. Toxicol. Environ. Health 45, 1-7.

Sakurai, T., Kim, J.G., Suzuki, N., Matsuo, T., Li, D.Q., Yao, Y.A., Masunaga, S., Nakanishi, J., 2000. Polychlorinated dibenzo-p-dioxins and dibenzofurans in sediment, soil, fish, shellfish and crab samples from Tokyo Bay area, Japan. Chemosphere 40, 627-640.

Schecter, A., Jiang, K., Papke, O., Furst, P., Furst, C., 1994. Comparison of dibenzodioxin levels in blood and milk in agricultural workers and others following pentachlorophenol exposure in China. Chemosphere $29,2371-2380$.
Schmid, P., Gujer, E., Zennegg, M., Bucheli, T.D., Desaules, A., 2005. Correlation of PCDD/F and PCB concentrations in soil samples from the Swiss soil monitoring network (NABO) to specific parameters of the observation sites. Chemosphere 58, 227-234.

Schuhmacher, M., Agramunt, M.C., Rodriguez-Larena, M.C., Diaz-Ferrero, J., Domingo, J.L., 2002. Baseline levels of PCDD/Fs in soil and herbage samples collected in the vicinity of a new hazardous waste incinerator in Catalonia, Spain. Chemosphere 46, 1343-1350.

Takigami, H., Sakai, S., Brouwer, A., 2005. Bio/chemical analysis of dioxin-like compounds in sediment samples from Osaka Bay, Japan. Environ. Technol. 26, 459-469.

United States Environmental Protection Agency (US-EPA), 2001. Database of Sources of Environmental Releases of Dioxin-like Compounds in the United States (Version 3.0). <http,//www.epa.gov/ncea/ Dioxin_Database/dioxindb.zip>.

Wong, M.H., Leung, A., Chan, J., Choi, M., 2005. A review on the usage of POP pesticides in China, with emphasis on DDT loadings in human milk. Chemosphere 60, 740-752.

Wu, W.Z., Schramm, K.W., Henkelmann, B., Xu, Y., Yediler, A., Kettrup, A., 1997. PCDD/F-s, PCBs, HCHs and HCB in sediments and soils of Ya-Er Lake area in China, results on residual levels and correlation to the organic carbon and particle size. Chemosphere 34, 191-202.

Wu, W.Z., Schramm, K.W., Henkelmann, B., Xu, Y., Zhang, Y.Y., Kettrup, A., 1998. Survey on PCDDs and PCDFs in sediments and soils in Ya-Er Lake area, China. Chin. J. Oceanol. Limnol. 16, 45-53.

Wu, W.Z., Schramm, K.W., Xu, Y., Kettrup, A., 2001a. Mobility and profiles of polychlorinated dibenzo- $p$-dioxins and dibenzofurans in sediment of Ya-Er Lake, China. Water Res. 35, 3025-3033.

Wu, W.Z., Schramm, K.-W., Xu, Y., Kettrup, A., 2002. Contamination and distribution of polychlorinated dibenzo-p-dioxins and dibenzofurans $(\mathrm{PCDD} / \mathrm{F})$ in agriculture fields in Ya-Er Lake area, China. Ecotoxicol. Environ. Safety 53, 141-147.

Wu, W.Z., Xu, Y., Schramm, K.W., Kettrup, A., 2001b. Persistence of polychlorinated dibenzo-p-dioxins and dibenzofurans $(\mathrm{PCDD} / \mathrm{F})$ in Ya-Er Lake area, China. Environ. Int. 26, 323-326.

Zhang, H., He, P.J., Li, G.J., Takeda, N., 2004. Dioxins measurement of municipal solid waste incineration ash. J. Tongji Univ. (Natural Science) 32, 1655-1659.

Zhang, Q.H., Wu, W., Zhan, W., Xu, Y., 2000a. Polychlorinated dibenzo$p$-dioxins and polychlorinated dibenzofurans in C.I. Violet 23 dyes and chloranil. Chin. J. Chromatogr. 18, 22-25.

Zhang, Q.H., Xu, Y., Wu, W.Z., Schramm, K.W., Kettrup, A., 2002. Reduction of polychlorinated dibenzo-p-dioxins and dibenzofurans levels in chloranil from China. Bull. Environ. Contam. Toxicol. 69, 459-462.

Zhang, Q.H., Xu, Y., Wu, W.Z., Xiao, R.M., Feng, L., Schramm, K.W., Kettrup, A., 2000b. PCDDs and PCDFs in the wastewater from Chinese pulp and paper industry. Bull. Environ. Contam. Toxicol. 64, 368-371.

Zheng, M., Zhang, B., Bao, Z.C., Yang, H., 2003. Analysis of PCDD/Fs from sediments of Dongting Lake in China. Organohal. Compd. 62, $190-192$.

Zheng, M.H., Bao, Z.C., Wang, K.O., Yang, H., Xu, X.B., 1997. Polychlorinated dibenzo-p-dioxins and dibenzofurans in lake sediments from Chinese schistosomiasis areas. Bull. Environ. Contam. Toxicol. 59, 653-656.

Zheng, M.H., Bao, Z.C., Xu, X.B., 1999. Formation mechanisms of dioxins during hypochlorite bleaching or chlorination of non-wood plant fibers pulp. Environ. Chem. 18, 526-531 (in Chinese).

Zheng, M.H., Chu, S.G., Sheng, G.Y., Min, Y.S., Bao, Z.C., Xu, X.B., 2001. Polychlorinated dibenzo-p-dioxins and dibenzofurans in surface sediments from Pearl River Delta in China. Bull. Environ. Contam. Toxicol. 66, 504-507. 